\title{
Epizootiological studies on viral haemorrhagic septicaemia in brown trout Salmo trutta fario
}

\author{
P.-J. Enzmann ${ }^{1}$, M. Konrad ${ }^{2}$, J. Rapp ${ }^{3}$ \\ ${ }^{1}$ Federal Research Centre for Virus Diseases of Animals, PO Box 1149, W-7400 Tübingen, Germany \\ ${ }^{2}$ Reqierungspräsidium Tübingen, Konrad-Adenauer-Str. 20, W-7400 Tübingen, Germany \\ ${ }^{3}$ Staatliches Tierärztliches Untersuchungsamt, Löwenbreitestr. 18-20, W-7960 Aulendorf, Germany
}

\begin{abstract}
The course of a VHS (viral haemorrhagic septicaemia) infection in brown trout Salmo trutta fario L. in a stream was followed for 4 yr using anti-VHS virus antibodies as the indication of infection. Trout were caught by electrofishing and the presence of anti-VHS virus antibody in the serum was determined by counter-current immunoelectrophoresis. There were fluctuations in the prevalence of antibodies to VHS virus in several distinct populations of brown trout varying from 6 to $67 \%$. In one population, the prevalence of antibody was found to be $41 \%$ in the first year of examination. In the following year the percentage increased to $67 \%$, then fell to $33 \%$ the next year and to $0 \%$ in the fourth year. Prevalence also varied with location in the stream. In one extreme case prevalence decreased from $37 \%$ to $10 \%$ over a stretch of only $3 \mathrm{~km}$. The antibody data indicate that the virus persisted in the brown trout populations for a considerable period because antibody titres were prevalent in the trout during 3 successive years of sampling. In the fourth year, however, the virus appeared to have been largely eliminated from the trout as only a few fish in one population showed evidence of the presence of virus.
\end{abstract}

Rainbow trout Oncorhynchus mykiss in aquaculture are assumed to be the main host for viral haemorrhagic septicaemia virus (VHS-V), a virus that has caused devastating infections in both rainbow trout fry and adults. A review of the disease has been given by Liversidge et al. (1985). In spite of good hygienic conditions, VHS outbreaks occur in farms which are supplied with stream water. Very often an outbreak of disease correlates with such factors as a drop in water temperature, water pollution, or other stress situations such as high stocking densities. These circumstances have been discussed in an earlier publication (Enzmann \& Konrad 1984). In the course of an investigation examining the health condition of brown trout in a stream that supplies 2 commercial fish farms rearing rainbow trout, sera of brown trout were tested for anti- bodies against. VHS-V (Enzmann \& Konrad 1985). On these farms severe VHS outbreaks had occurred about 6 mo prior to the first sampling of the brown trout. In previous reports brown trout were described to be sensitive to serotypes $\mathrm{He}$ and 23.75 of VHS-V and to be refractory to serotype F1 (Jørgensen 1972, Jørgensen 1980, de Kinkelin \& Le Berre 1977). The detection of antibodies against serotype F1 in brown trout initiated the present epizootiological studies on VHS among the feral brown trout. We were particularly interested in following the time course of antibody development and disappearance, and we did so over a period of several years.

Materials and methods. Cells and virus strains: The RTG-2 (rainbow trout gonad) cell line, purchased from Flow, Bonn, Germany, was used for virus propagation. VHS-V strain F1 was obtained from Dr P. E. V. Jørgensen, State Veterinary Serum Laboratory, Aarhus, Denmark. The virus strain was cloned by 8 end-point dilutions in RTG- 2 cells. For production of antigen, virus was grown in RTG-2 cells. Virus isolated from infected rainbow trout after VHS outbreaks in trout farms was determined to belong to the F1 serotype using the neutralization test: it was strongly neutralized with antiserum prepared against the F1 serotype but only feebly neutralized with antisera prepared against other VHS serotypes.

Antibody detection assay: Antibodies to VHS-V were detected by means of counter-current immunoelectrophoresis in $1 \%$ agarose gels with high electroendosmosis using barbiturate buffer $(\mathrm{pH} 8.2 ; 0.05 \mathrm{M})$ as described earlier (Deuter \& Enzmann 1986). The tests were performed using a potential difference of $5 \mathrm{~V} \mathrm{~cm}^{-1}$. The distance between the centres of the wells was 7 $\mathrm{mm}$. Sera $(15 \mu \mathrm{l})$ were applied to loading wells which 
were $3 \mathrm{~mm}$ in diameter. Supernatant of infected cell cultures $(15 \mu \mathrm{l})$, treated with $1 \%$ Triton $X-100$, was used as antigen in the opposite loading well. The electrophoretic run took about $90 \mathrm{~min}$. The plates were stored overnight in a solution of $1 \mathrm{M}$ sodium chloride to remove non-reacting proteins after which they were dried and stained with Coomassie blue.

Specificity of the antibody detection assay: The specificity of the antigen-antibody reaction detected in counter-current immunoelectrophoresis was examined by the indirect immunofluorescence assay and by the

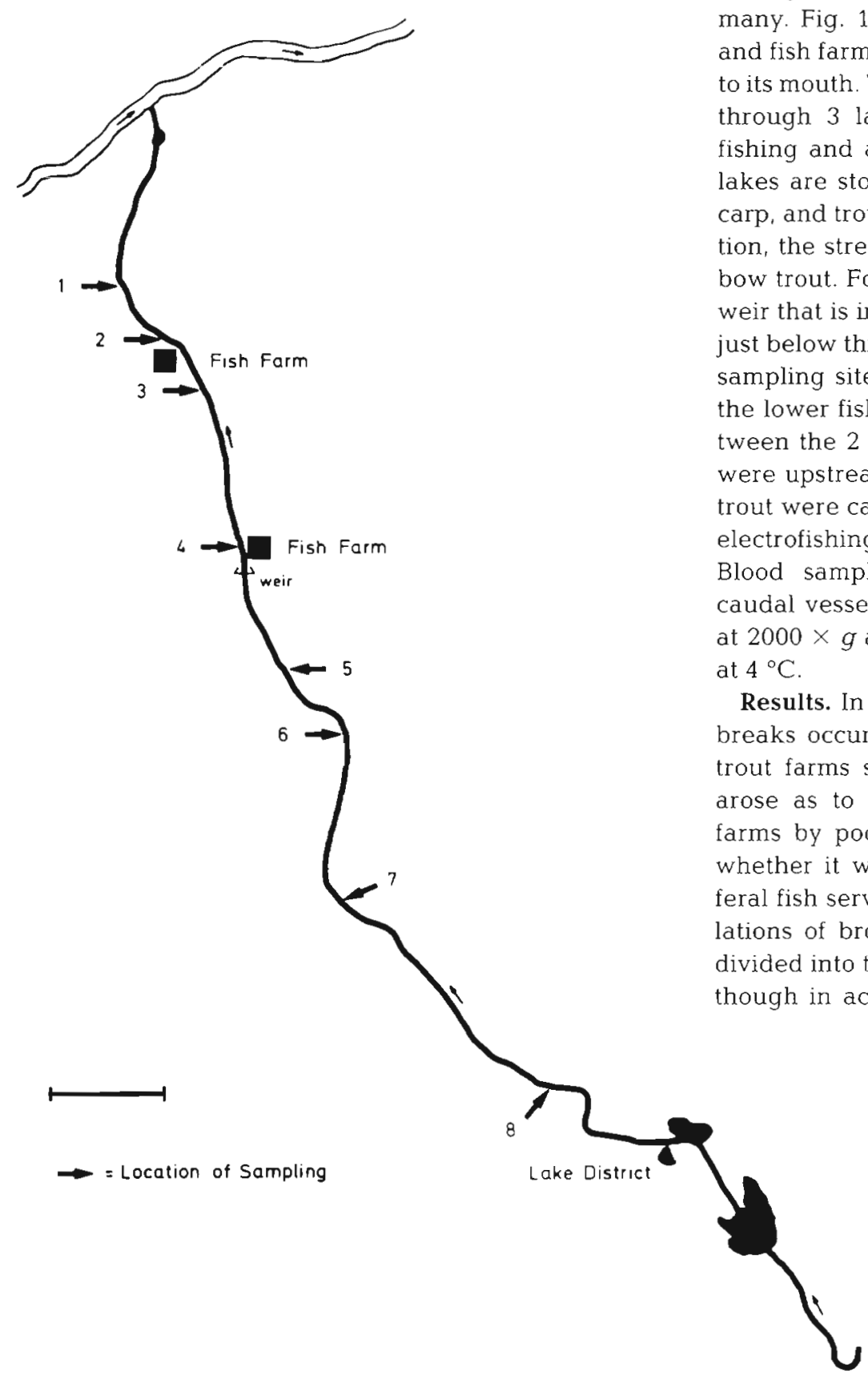

Fig. 1. Sampling locations and fish farm sites. (Scale bar $=2 \mathrm{~km}$ ) neutralization test. Sera from brown trout containing known antibody titers against VHS-V were used for this purpose. In the indirect immunofluorescence assay, the fluorescence obtained by treatment of infected cells with an antiserum from rabbit followed by staining with FITC-conjugated anti-rabbit immunoglobulin was extinguished by pretreatment of the infected cells with the trout sera containing antibodies against VHS-V. The neutralization test utilized VHS-V and the brown trout sera and was performed as described by Wizigmann et al. (1983).

Field studies: Brown trout were collected by electrofishing from 8 sites along a stream in southern Germany. Fig. 1 shows the locations of the sample sites and fish farms. The brook is $28 \mathrm{~km}$ long from its source carp, and trout as well as some eel and catfish. In addition, the stream is stocked with brown trout and rainbow trout. Fourteen $\mathrm{km}$ below the lake area there is a weir that is impassable to fish. Trout farms are located just below this weir and $3 \mathrm{~km}$ downstream from it. Two were upstream of the upper fish farm. At each site 30 trout were caught in each of the years 1983 to 1986 by electrofishing over a stretch of about 200 to $300 \mathrm{~m}$ Blood samples were collected by puncturing the caudal vessel. Serum was collected by centrifugation at $2000 \times g$ after allowing a clot to develop overnight $4{ }^{\circ} \mathrm{C}$

In spring and in December 1983, VHS outarose as to whether VHS-V was introduced to the farms by poor management or hygienic practices or whether it was enzootic in the region, with infected feral fish serving as the source of the virus. The populations of brown trout in the stream can be roughly divided into those living above and below the weir, alhough in actual fact additional subpopulations exist 
since brown trout exhibit a homing behaviour. A first sampling of brown trout for VHS-V specific antibodies was performed during November 1983 at 4 distinct sites $(2,3,4,5)$ on the stream upstream and downstream of the farms (Fig. 1) (Enzmann \& Konrad 1985). The results of this examination stimulated interest in a continuation of the study. Sampling from 1984 to 1986 was extended to locations over the entire stretch of the stream. Four additional sample sites were chosen $(1,6$, $7,8)$. In the November 1983 sampling, brown trout from the study area exhibited a high prevalence of antibodies against VHS-V strain F1, particularly those collected below the farms (antibody prevalence at Sites 2 and 4 was $41 \%$ and $37 \%$, respectively). This was the same strain that had caused the VHS outbreaks in the rainbow trout farms. However, even upstream of the impassable weir and fish farms, VHS-V strain F1 antibodies were detected in the brown trout (Site 5, $21 \%$ ). It appeared, therefore, that the VHS outbreak in the fish farms was initiated by infected feral fish. The percentage of fish with antibodies is shown in Fig. 2. Within a stretch of $3 \mathrm{~km}$ between the 2 fish farms the percentage of antibody-positive fish decreased from $37 \%$ to $10 \%$ (Sites 4 and 3 ). In the following year (1984), the percentage of antibody-positive fish was even higher with a maximum of $67 \%$ at Site 2 , although the distribution was comparable with that of the previous year. At the time of this sampling, the fish farms had been free of VHS for 6 mo. In the third year of sampling (1985) the highest percentage of antibody-

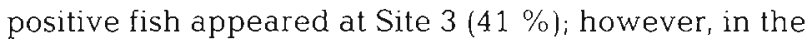
following year (1986) the infection of brown trout, which was inferred from the presence of specific antibodies, had nearly disappeared at this site $(6 \%)$ and was not seen at any of the other 7 sites. The prevalence of antibodies fluctuated for example on site 2 from $41 \%(1983)$ to $67 \%(1984)$ to $33 \%$ (1985) and to $0 \%$ (1986).

Discussion. It was recently shown in both field trials and experimental infections that brown trout are susceptible to VHS-V strain F1 (Enzmann \& Konrad 1985, Konrad \& Enzmann 1987). The infection that developed was inapparent (subclinical) but was associated with a demonstrable viremia and was followed by the appearance of antibodies against VHS-V about $20 \mathrm{~d}$ post infection. The detection of VHS-V antibodies in brown trout is therefore good evidence that the trout were infected with VHS-V. The spread of VHS-V within a brown trout population can thus be measured by an antibody survey.

The investigations described here strongly suggested that infections with VHS-V in rainbow trout farms in southern Germany were carried from the feral fish population of the stream into the fish farms. After the VHS-outbreaks in the fish farms, virus was shed con-

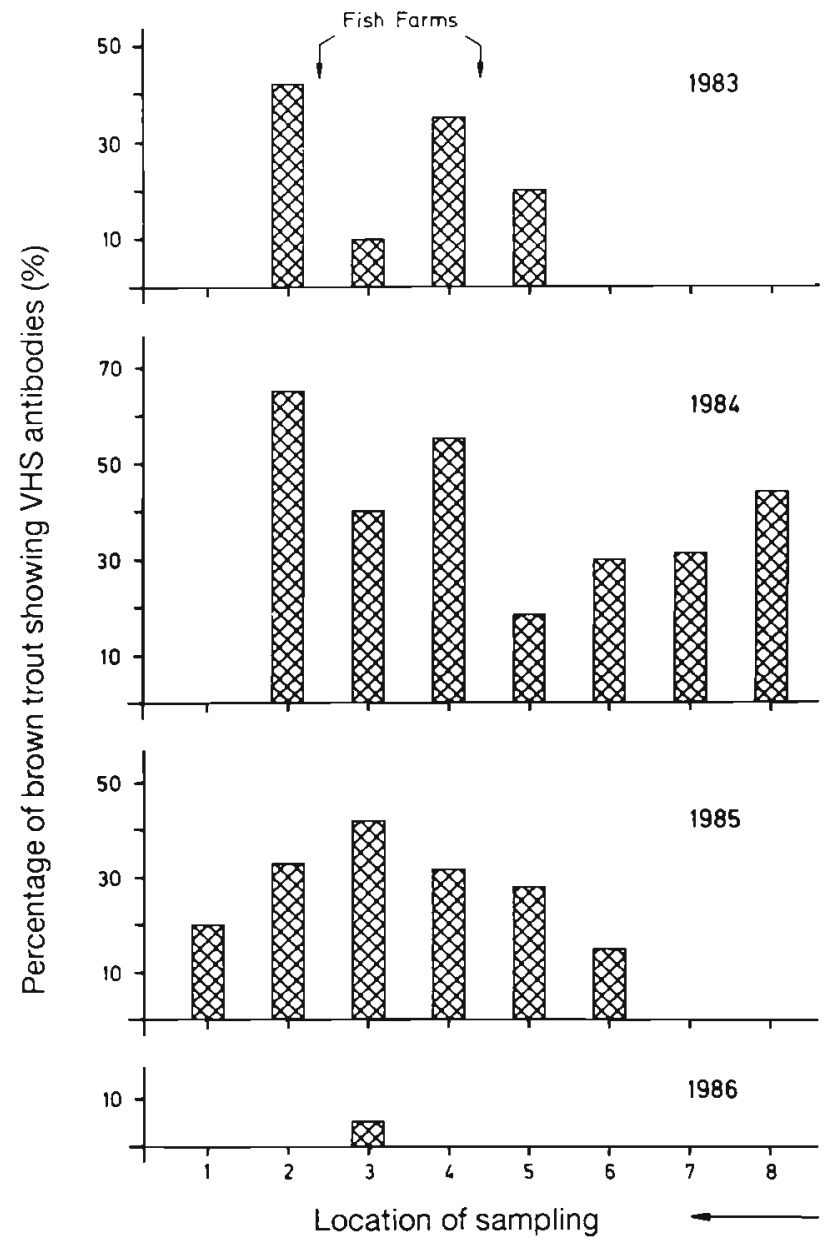

Fig. 2. Salmo trutta fario. Prevalence of antibodies against VHS- $V$ in brown trout caught at 8 sites over a 4 yr period. Arrow: direction of water flow

tinuously into the water for several weeks (Enzmann unpubl.). The fact that antibodies were found in fish upstream of a weir that is impassable to fish indicates that fish in the entire river system were affected by the virus.

It is assumed that there are no significant movements of fish within the stream since brown trout can be categorized as resident (Stuart 1957, Solomon \& Templeton 1976). Fish sampling was performed before the onset of spawning migration in autumn. Periodic examinations of fish from the stream following the VHS epizootics in the 2 fish farms located on the stream suggested that the virus infection (as evidenced by the prevalence of specific antibodies) persisted in the populations of brown trout for 3 to 4 yr. Within the brown trout populations in the stream the number of infected fish varied over the 4 yr observation period. At Site 3 the number of infected fish increased during the initial $3 \mathrm{yr}$ of observation and then declined in the fourth year. At 
Sites 2 and 4, however, infection rates rose only until the second year following which they declined. At yet another site (5), the infection rate declined in the second year, rose in the third year, and declined again in the fourth year. The infection persisted longest in the population of brown trout with the lowest prevalence of infection at the beginning of the epizootic (Site 3. Fig. 2). These observations point out that the brown trout infections persisted until a large proportion of the brown trout population became immune. At this point, herd immunity was achieved and the infection tended to disappear.

The infection apparently originated from the pike in the lake district (Fig. 1) which had been shown earlier to be infected with VHS- $V$ as evidenced by a prevalence of antibodies in up to $33 \%$ of the tish sampled (Enzmann et al. 1987). In contrast to brown trout where the prevalence of the infection decreased within 4 yr (Fig. 2), the infection in pike persisted at a high level for many years (Enzmann et al. 1987). In areas where VHS-V is enzootic, prevalence of VHS-V in brown trout tends to be at a very low level due to the low pathogenicity of the virus for this species. Notwithstanding this, as demonstrated in the investigation described here, brown trout can function as VHS-V carriers for extended periods, as was predicted in an earlier work (Konrad \& Enzmann 1987).

Acknowledgements. We thank Mrs I. Fabian for her excellent technical assistance. The study was supported by the Ministerium für Ernährung, Landwirtschaft. Umwelt und Forsten, Baden-Württemberg.

\section{LITERATURE CITED}

Deuter, A., Enzmann, P.-J. (1986). Comparative biochemical and serological studies on two fish-pathogenic Rhabdoviruses (VHS-V and SVC-V). J. Vet, Med. B33: 36-46

Enzmann, P.-J., Konrad, M. (1984). Die Virale Hämorrhagi-

Responsible Subject Editor: T. Evelyn, Nanaimo, B.C. Canadā sche Septikämie der Regenbogenforelle (VHS) und ihre Bekämpfung in epidemiologischer Sicht. Tierärztl. Umsch 39: $886-892$

Enzmann, P.-J., Konrad, M. (1985). Inapparent infections of brown trout with VHS-virus. Bull. Eur. Ass. Fish Pathol. 5: $81-83$

Enzmann, P.-J, Konrad, M., Parey, K. (1987). Verbreitung der VHS in verschiedenen Hechtpopulationen Süddeutschlands. In: DVG (ed.) Tagung der Fachgruppe 'Fischkrankheiten'. Deutsche Veterinärmedizinische Gesellschaft, Gießen/Lahn, p. 19-22

Jørgensen, P. E. V. (1972). Egtved virus: antigenic variation in 76 virus isolates examined in neutralization tests and by means of the fluorescent antibody technique. Symp. Zool. Soc. Lond. 30: 333-340

Jørgensen, P. E. V. (1980). Egtved virus: the susceptibility of brown trout and rainbow trout to eight virus isolates and the significance of the findings for the VHS control. In Anne, $w$. (ed.) Fish diseases. Inird CUPRAQ-Session. Springer Verlag, Berlin, p. 3-7

de Kinkelin, P., Le Berre, M. (1977). Isolement d'un rhabdovirus pathogène de la truite fario (Salmo trutta, L.). C. r. Acad. Sci., Paris, Serie D 284: 101-104

Konrad, M., Enzmann, P.-J. (1987). Infektionsversuche zur Ubertragung des VHS-V von der Bachforelle (Salmo trutta fario L.) und vom Hecht (Esox lucius L.) auf die Regenbogenforelle (Salmo gairdneri Richardson). In: DVG (ed.) Tagung der Fachgruppe 'Fischkrankheiten'. Deutsche Veterinärmedizinische Gesellschaft, Gießen/Lahn, p. 23-29

Liversidge, J., Munro, A. L. S., Schlotfeldt, H.-J., Evelyn, T. P. T (1985). Fischpathogene Viren. In: Roberts, R. J., Schlotfeldt, H.-J. (eds.) Grundlagen der Fischpathologie. Paul Parey Verlag, Berlin, p. 112-173

Solomon, D. J., Templeton, R. G. (1976). Movements of brown trout Salmo trutta L. in a chalk stream. J. Fish Biol. 9: $411-423$

Stuart, T. A. (1957). The migrations and homing behaviour of brown trout (Salmo trutta). Freshwat. Salm. Fish. Res. 18: $1-27$

Wizigmann, G., Ahne, W., Schlotfeldt, H.-J. (1983). Laboratoriumsdiagnose von Virusinfektionen bei Süßwasserfischen unter besonderer Berücksichtigung der viralen hämorrhagischen Septikämie (VHS), der infektiösen Pankreasnekrose (IPN) und der Frühlingsvirämie (SVC). Teil II. Tierärztl. Umsch. 38: 129-131

Manuscript first received: September 6, 1991 Revised version accepted: December 11, 1991 